\author{
Jacek Strojny \\ Wyższa Szkoła Informatyki i Zarządzania w Rzeszowie \\ Politechnika Rzeszowska \\ Magdalena Berezowska \\ Wyższa Szkoła Informatyki i Zarządzania w Rzeszowie
}

\title{
Przedsiębiorczość jako determinanta konkurencyjności organizacji zorientowanej projektowo
}

\section{Zmiana i wynikająca z niej niepewność jako determinanty rozwoju}

Wśród określeń najpełniej charakteryzujących świat, w którym funkcjonują współczesne organizacje, najważniejszym jest zmiana. Nie ulega wątpliwości, że jest ona czymś powszechnym, wszechobecnym, czymś, czego organizacje nie mogą uniknąć.

Szukając odpowiedzi na pytanie, czym jest zmiana, warto sięgnąć po propozycje, których liczne przykłady można znaleźć w literaturze przedmiotu. Z. Mikołajczyk i K. Zieniewicz pod pojęciem zmiany rozumieją proces , przeobrażeń, zmieniających istotę rzeczy lub zjawisk”" Można zatem powiedzieć, że jeśli w jakimś ,systemie czy układzie społecznym powstają nowe elementy składowe lub znikają elementy dotychczas występujące, lub jeżeli powstają nowe stosunki między tymi elementami czy znikają stosunki dotychczas istniejące, mówimy, że system ten ulega zmianie" (Karwińska, Mikułowki-Pomorski, Pacholski 2002).

Biorąc pod uwagę natężenie zmian, można wyróżnić trzy podstawowe stany otoczenia: 1 . stabilizacja; 2. zmienność; 3. burzliwość (Stoner, Wankel 1996). Pierwszy z wymienionych w klasyfikacji stanów - otoczenie stabilne - charakteryzuje się niewielkim natężeniem zmian nagłych i nieoczekiwanych. Pozwala to na planowanie rozwoju firmy w długim horyzoncie czasowym. W takiej sytuacji również na poziomie organizacji obserwuje się stagnację i rozwój ewolucyjny. Znacznie większe wymagania stawia otoczenie zmienne, w którym skala zmian jest duża. Jednocześnie są one efektem trwałych tendencji, co daje możliwość przewidywania kierunku zmian. Oczywiście firmy muszą wdrażać programy zmian wewnątrzorganizacyjnych. Jednak prawidłowo zbudowany system monitoringu otoczenia pozwala ograniczyć ryzyko błędów. Najwięcej wyzwań dla zarządzających organizacją stwarza otoczenie burzliwe. Zmiany mają w nim dużą skalę, w dodatku pojawiają się bez wyraźnych tendencji. Często mają one charakter rewolucyjny, wynikający z innowacyjności wyrobu lub procesu. W takiej sytuacji organizacja musi jednocześnie przedsięwziąć dwa typy działań. Po pierwsze, należy usprawnić proces monitorowania otoczenia. Po drugie, konieczne jest wykazanie elastyczności proaktywnej, czyli wyprzedzanie zmian, a nawet ich kreowanie. Te dwa atrybuty organizacji mogą decydować o zdolności przedsiębiorstwa do zbudowania przewagi konkurencyjnej. Pozwalają one kierującym na niwelowanie niepewności decyzyjnej wynikającej ze zmienności otoczenia.

\footnotetext{
${ }^{1}$ Z. Mikołajczyk, K. Zieniewicz, 1999, Zarzqdzanie matym przedsiębiorstwem [w:] Ekonomika i zarzadzanie mała firma, B. Piasecki (red.), Wydawnictwo Naukowe PWN, Warszawa [za:] J. Majchrzak, 2002, Zarzq̨dzanie zmianami w przedsiębiorstwie, Wyd. AE w Poznaniu, Poznań.
} 
Ryc. 1. Rodzaje otoczenia firmy

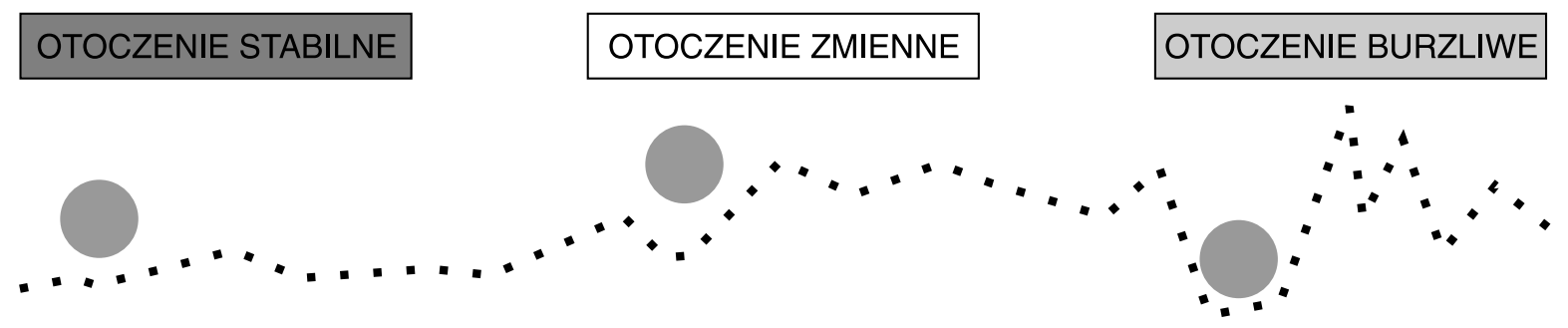

Źródło: opracowanie autorów na podstawie: Stoner, Wankel 1996

Sam stopień zmienności nie wystarcza jednak, aby skutecznie opisać zewnętrzne warunki funkcjonowania organizacji. Zmienność mówi bowiem tylko o tym, w jakim stopniu otoczenie jest stabilne, a w jakim burzliwe. Ważny jest także stopień jednorodności. Chodzi o zidentyfikowanie czynników (elementów) kształtujących sytuację w otoczeniu. Jednorodność wskazuje zatem, czy otoczenie jest proste, czy złożone. Dopiero oba te wymiary łącznie pozwalają określić poziom niepewności wynikający z sytuacji w otoczeniu. Właśnie ta niepewność jest zjawiskiem determinującym funkcjonowanie organizacji i wymuszającym na nich stosowanie rozwiązań zwiększających elastyczność (np. zarządzania projektowego).

Ryc. 2. Zmienność i jednorodność jako atrybuty otoczenia firmy

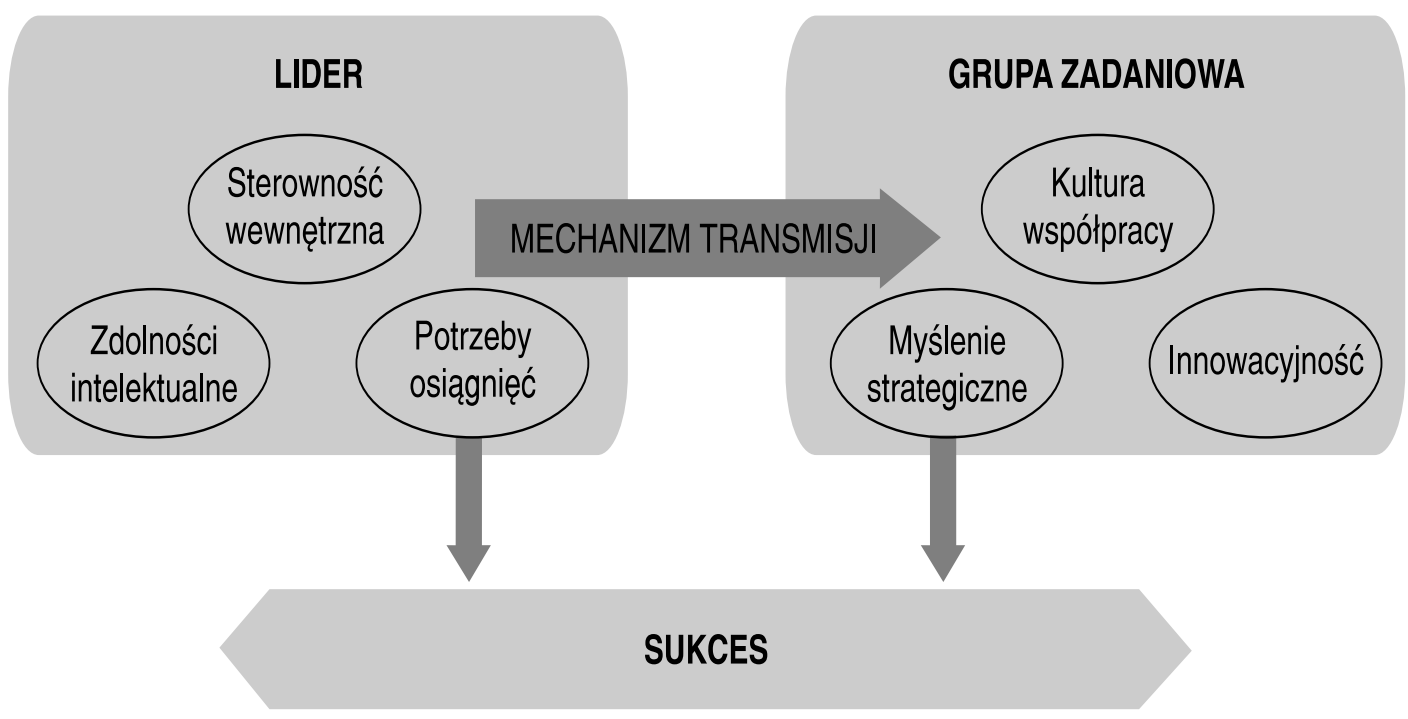

Źródło: opracowanie autorów na podstawie: J.D. Thompson, 1967, Organizations in Action, McGraw-Hill, New York [za:] R.W. Griffin, 1999, Podstawy zarządzania organizacjami, Wydawnictwo Naukowe PWN, Warszawa

Przyczyn zmienności i niepewności otoczenia jest wiele. R.B. Kuc (2004) próbuje je wymienić, wskazując na cztery podstawowe źródła zmian: 1. globalizacja i internalizacja konkurencji; 2 . deregulacja procesów i zmniejszenie barier ekspansji; 3. dojrzewanie rynków; 4. przyspieszenie postępu naukowego (techniki i technologii). Można stwierdzić, że przyczyną omawianych tendencji jest globalizacja. Zjawisko to jest przedmiotem zainteresowania wielu dyscyplin naukowych. Na potrzeby niniejszego artykułu wystarczy stwierdzić, że jest to zjawisko złożone i wielowymiarowe, tzn. ujawnia się w wielu obszarach życia społeczno-gospodarczego, szczególnie 
w technice i technologii, kulturze oraz gospodarce. „W dziedzinach związanych z gospodarką do jej cech zaliczano integrowanie, scalanie i wzajemne przenikanie prowadzonej w skali międzynarodowej działalności na różnych poziomach: produkcji, dystrybucji i handlu, co w rezultacie niosło wzrost międzynarodowej współzależności systemu gospodarczego" (Nowakowski, Wajszczuk 2003).

\section{Przedsiębiorczość jako atrybut organizacji konkurencyjnej}

Zmienność, niepewność, globalizacja - te terminy są wymieniane przez wielu autorów przy okazji rozważań na temat zarządzania współczesnym przedsiębiorstwem. Jest to zrozumiałe, ponieważ za tymi terminami kryją się determinanty, które stwarzają nowe wyzwania.

Warunki, w jakich przychodzi się rozwijać współczesnym przedsiębiorstwom, powodują konieczność zmiany sposobów konkurowania, a co za tym idzie - także zmiany strategii organizacji (Kasiewicz 1999). J. Machaczka (2004) dostrzega ten problem, podkreślając, że tylko dzięki innowacyjności, jakości, elastyczności i dynamice firmy mogą przetrwać i się rozwijać. Inny autor J. Penc (2001) - mówi o coraz większym nacisku na innowacyjność, elastyczność, efektywność i szybkość wprowadzania nowych rozwiązań. S. Kasiewicz (1999) stwierdza, że w zglobalizowanej gospodarce konkurencyjność organizacji wymaga budowania proaktywnej reakcji przedsiębiorstwa na zmiany w otoczeniu.

Wszyscy wymienieni autorzy są zgodni w kwestii konieczności wdrażania nowego modelu konkurowania. Model ten powinien zwiększać elastyczność organizacji. „Elastyczność rozumiana także jako zwinność, mobilność stanowi powszechnie akceptowaną cnotę i pożądaną cechę współczesnego przedsiębiorstwa w warunkach konkurencji globalnej (...)" (Osbert-Pociecha 2004). Ta cecha jest zatem miarą pozwalającą na określenie stopnia adaptacyjności organizacji (Holstein-Beck 1997).

Dzięki elastyczności jest zatem możliwe skuteczne przeprowadzanie zmian organizacyjnych. Zjawisko to obejmuje szereg procesów dostosowujących organizację do wymagań stawianych przez otoczenie [Szplit (red.) 1996]. Istotą tych procesów jest zastapienie stanu istniejącego stanem odmiennym, ale jednocześnie podnoszącym przedsiębiorstwo na wyższy poziom rozwoju (Kurek 2001). Wynika stąd postulat, że te zmiany, które są projektowane i realizowane w ramach współczesnych organizacji, powinny mieć charakter innowacyjny i tworzyć nowąjakość funkcjonowania (Penc 2005).

Wprowadzenie do rozważań pojęcia ,innowacje” daje podstawę do wysunięcia tezy, że podstawowym atrybutem organizacji konkurencyjnej jest przedsiębiorczość. Jak słusznie stwierdza W. Janik (2003), zjawiska innowacji i przedsiębiorczości są ze sobą nierozerwalnie związane. O znaczeniu i sukcesie przedsiębiorczości ,przesądza (zatem) tworzenie innowacji oraz doskonalenie wyrobów i ich rynkowe wykorzystanie, czyli dobry interaktywny marketing i nowe lub udoskonalone wyroby wprowadzane po to, by lepiej zaspokoić potrzeby klientów i pokonać konkurencję przewagą wartości” (Stopczyńska, Karkowski 2003).

Czymże zatem jest ta przedsiębiorczość? Odpowiedź nie jest łatwa. Mimo że uczeni są zgodni co do roli przedsiębiorczości w życiu społeczno-gospodarczym, różnią się w rozumieniu tego pojęcia. Widoczne jest to szczególnie wówczas, gdy bierze się pod uwagę wielość jego definicji. Przedsiębiorczość nie jest bowiem zjawiskiem jednolitym. W. Janasz (2004) określa ją nawet jako kategorię wielowymiarowa, wyjaśnianą za pomocą różnych zmiennych. Jej wyjaśnianie wymaga zatem również podejścia interdyscyplinarnego.

Dzięki temu możliwe jest zrozumienie zjawiska przedsiębiorczości z punktu widzenia różnych dziedzin nauki: 1. psychologii; 2. socjologii; 3 . ekonomii; 4. organizacji i zarządzania. Tworzą się w ten sposób cztery wymiary przedsiębiorczości, przedstawione na ryc. 3 . 
Ryc. 3. Przedsiębiorczość jako zjawisko wielowymiarowe

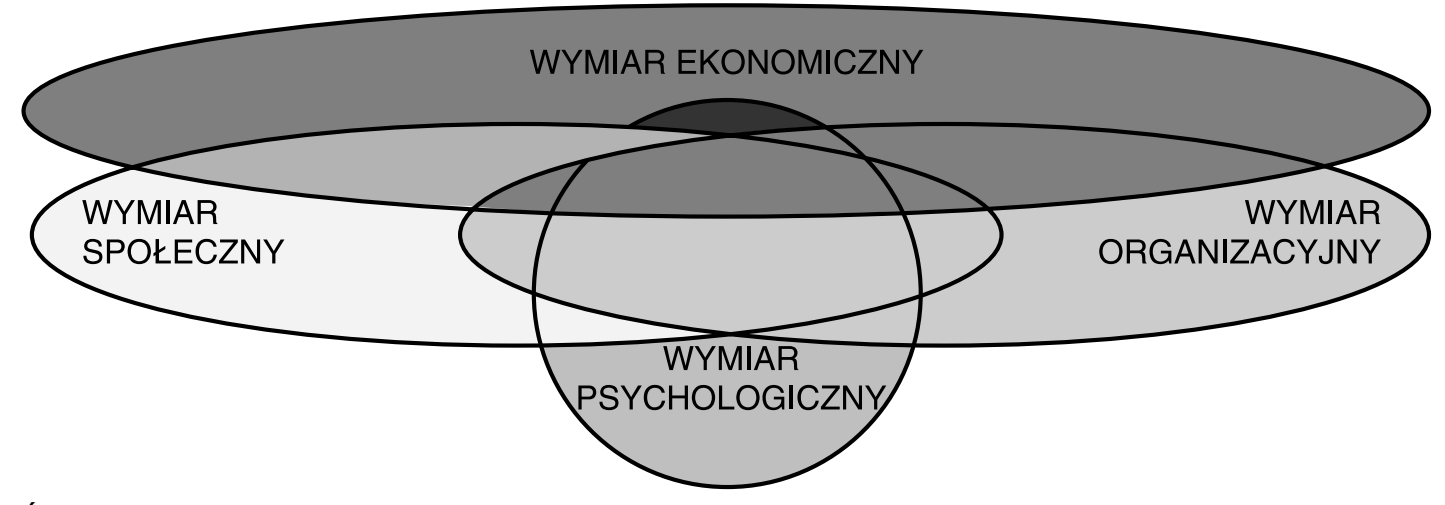

Źródło: opracowanie autorów

W ujęciu psychologicznym przedsiębiorczość może być rozumiana ,jako cecha określonych osób, które są skłonne i zdolne inicjować oraz realizować nowe, odważne działania" (Zaleśkiewicz 2004). A. Francik (1994) wyraża się podobnie, określając przedsiębiorczość jako swego rodzaju cechę danej osoby albo sposób, w jaki ona się zachowuje. „W tym nurcie mieści się określenie przedsiębiorczości, przyjmujące, że jest to cecha osobowości charakteryzująca postawy i zachowania ludzkie, polegająca na zdolności i chęci ponoszenia ryzyka, skłonności do zachowań innowacyjnych oraz podejmowania działań w celu wykorzystania nadarzających się szans i okazji” (Kożuch 2001). M. Bratnicki (2002) dodaje, że przedsiębiorcze nastawienie umysłu pozwala na tworzenie wartości, na uzyskanie korzyści z niepewności (nieokreśloności).

T. Listwan (2004) stwierdza, że ludzka, indywidualna przedsiębiorczość znajduje odzwierciedlenie w takich działaniach, jak inicjowanie projektów gospodarczych, kreatywne rozwiązywanie problemów, podejmowanie ryzyka, wykorzystywanie okazji czy elastyczne dostosowywanie organizacji do warunków otoczenia. W podobnym duchu przedsiębiorczość rozumie T. Kraśnicka (2002), nazywając ją działaniem menedżerskim i wykonawczym, polegającym na wykorzystywaniu okazji i ponoszeniu ryzyka, które w efekcie przynosi korzyści. To podkreślanie wartości dodanej czy efektywności uzyskiwanej dzięki działalności przedsiębiorczej jest charakterystyczne dla ujęcia ekonomicznego.

Już w tych definicjach podkreśla się, że przedsiębiorczość może być nie tylko cechą człowieka, ale także cechą organizacji [Lichtarski (red.) 1999]. Aby jednak tak było, aby skutecznie wykorzystywać szanse i wprowadzać innowacyjne zmiany, wymagane jest zarządcze podejście do przedsiębiorczości. Jak zauważa J.D. Antoszkiewicz (2002), można zatem mówić o przedsiębiorczym zarządzaniu, które ujawnia się odpowiednią polityką w następujących obszarach: 1. klimat przedsiębiorczy; 2. kultura organizacji; 3. wspomaganie samokształcenia; 4. przeciwdziałanie barierom rozwoju. Takie rozumienie przedsiębiorczości wynika z podejścia organizacyjnego.

W rozumieniu społecznym ,przedsiębiorczość to umiejętne i społecznie akceptowane, a przy tym ukierunkowane na rozwój, funkcjonowanie jednostek i grup ludzkich w ramach gospodarki rynkowej" (Kożuch 2001).

Niezależnie od wymiaru, który jest podstawą definiowania, bezdyskusyjne wydaje się to, że w każdym rozumieniu przedsiębiorczość traktowana jest jako podstawowy atrybut podnoszący konkurencyjność we współczesnym świecie. W związku z tym można zaproponować ogólną definicję, która niejako łączy wszystkie te podejścia. Przedsiębiorczość jest to zatem względnie trwała kompetencja osoby, grupy, organizacji lub systemu gospodarczego, która przejawia się dynamicznym reagowaniem na zjawiska pojawiające się w otoczeniu i przynosząca efekt w postaci przejścia na wyższy poziom rozwoju. 


\section{Budowanie przedsiębiorczości w organizacji projektowej}

Przedsiębiorczość jest zjawiskiem, które występuje w różnego rodzaju organizacjach, szczególnie w tych, które są zorientowane projektowo. Realizacja projektów w ramach specjalnie powołanych zespołów zadaniowych może bowiem być traktowana jako przejaw przedsiębiorczości. Na pewno powoływanie takich zespołów jest rozwiązaniem zwiększającym elastyczność i ułatwiającym wprowadzanie zmian organizacyjnych.

W ramach organizacji projektowych wyodrębniane są grupy zadaniowe. Można je traktować jako pewien szczególny typ grupy społecznej. W literaturze wskazuje się, że są one powoływane w celu realizacji określonego zadania (Robbins 1998). Oczywiście wspólny cel jest podstawą tworzenia się wszystkich grup społecznych (Domachowski 1998), jednak w przypadku grupy zawodowej ten cel wynika z przyjętych planów rozwojowych organizacji, w ramach której grupa jest formowana. W przypadku zaawansowanych rozwiązań organizacyjnych ludzie mogą tworzyć zespoły projektowe, które dysponują także zbiorem zasobów wyodrębnionych na potrzeby konkretnego projektu (Lock D. 2003).

Problematykę zarządzania przedsiębiorczego można rozpatrywać z punktu widzenia kilku różnych perspektyw. Nie ulega wątpliwości, że przedsiębiorczość, nawet jako atrybut organizacji, warunkowana jest przede wszystkim przez czynnik ludzki. Należy jednak zwrócić uwagę, że oprócz ogólnych problemów związanych z funkcjonowaniem człowieka w organizacji, dostrzegalna jest pewna specyfika organizacji projektowej. Można powiedzieć, że praca w ramach zespołów zadaniowych stawia człowiekowi większe wymagania niż praca $\mathrm{w}$ organizacjach zarządzanych tradycyjnie, z kilku powodów, m.in.: 1. projekty cechują się dużą złożonością i niepowtarzalnością; 2. pracownicy muszą mieć wysokie kwalifikacje wejściowe; 3. wymaga się umiejętności pracy zespołowej (Trocki, Grucza, Ogonek 2003). Oczywiście należy zwrócić uwagę na to, że w ramach zespołów funkcjonują zwykle osoby o wiedzy specjalistycznej i wysokich kompetencjach, co stwarza dodatkowe wyzwania, szczególnie liderom zespołów. Wydaje się zatem słuszna teza, że istotnym zagadnieniem dotyczącym budowania przedsiębiorczości jest zapewnienie skutecznego przywództwa projektowego. Chodzi tutaj o dobór lidera, który powinien się charakteryzować określonymi cechami przedsiębiorczymi. Po drugie, należy się zastanowić nad cechami grupy, jakie powinny zostać zapewnione, aby można ją było nazwać przedsiębiorczą. Trzecim elementem jest budowanie procesu transmisji przedsiębiorczości lidera na poziom grupy.

Warto również zwrócić uwagę na to, że dzięki przedsiębiorczości jest możliwe zbudowanie układu proaktywnego. Oznacza to, że jednostki, grupy czy organizacje cechujące się przedsiębiorczością potrafią nie tylko dostosowywać się do zmian w otoczeniu, ale też wyprzedzać, a nawet kreować zmiany. A wszystko po to, aby osiagnnąć sukces, czyli zrealizować przyjęte cele.

Projekt wymaga szczególnego rodzaju przywództwa. Niepowtarzalność celów powoduje wzrost niepewności, a zróżnicowany skład zespołu stwarza duże wymagania względem kultury organizacyjnej i klimatu pracy (Heerkens 2003). Można zatem zaryzykować stwierdzenie, że wymagania względem przedsiębiorczości lidera projektu są większe, niż w przypadku przywódców funkcjonujących w ramach organizacji tradycyjnych.

Proponuje się, aby cechy przedsiębiorcze lidera opisać w postaci trzech podstawowych wymiarów: 1. potrzeby osiagnięć; 2. sterowność wewnętrzna; 3. zdolności intelektualne (Strojny 2006). Zastanawiając się nad pierwszym z wymienionych kryteriów, należy stwierdzić, że potrzeby osiagnnięć wskazują kierunek rozwoju indywidualnego lidera. Ich przejawem jest dążenie zarówno do osiagnięcia sukcesu, jak i do spełnienia się w pracy; są nimi także skłonności do poprawy statusu materialnego czy do wywierania wpływu. Aby skutecznie zarządzać zespołem projektowym, lider musi mieć wszystkie te cechy. Człowiek nimi obdarzony skłonny jest do 
podejmowania walki, do konkurowania z innymi, ale także do bycia lepszym. Jednak niemożliwe jest podejmowanie konkretnych działań w celu osiagnnięcia sukcesu osobistego, jeżeli potrzebom osiagnięć nie towarzyszy sterowność wewnętrzna. Obejmuje ona grupę cech, które powoduja, że lider wierzy w siebie, jest niezależny i odpowiedzialny, optymistycznie patrzy w przyszłość, a dzięki temu jest otwarty na zmiany i innych ludzi. Sterowność wewnętrzna daje więc poczucie bezpieczeństwa i pogodę ducha. Podstawowym źródłem przewagi - instrumentem konkurowania przywódcy - są jego zdolności intelektualne. Ważne są także takie cechy, jak inteligencja, kreatywność czy różnego rodzaju uzdolnienia do wykonywania określonych czynności.

Czym powinna się charakteryzować przedsiębiorcza grupa zadaniowa? Zidentyfikowano trzy podstawowe grupy cech: 1. myślenie strategiczne; 2. kultura współpracy; 3. innowacyjność. Pierwszy wymieniony wymiar - myślenie strategiczne - ma pewną specyfikę w przypadku organizacji zorientowanej projektowo. Otóż, cele ustalane są na poziomie całej organizacji. Zadaniem zespołu zadaniowego (jego celem) jest natomiast realizacja konkretnego projektu. Sytuację komplikuje to, że cele poszczególnych członków zespołu mogą być ustalane na podstawie celów macierzystych jednostek organizacyjnych. Może zatem rodzić się konflikt pomiędzy poszczególnymi celami. Grupa zadaniowa, aby sprawnie funkcjonować, musi więc być świadoma ogólnej wizji strategicznej i - mając tę wizję na uwadze - podejmować działanie w ramach konkretnego projektu. Ważne są oczywiście także umiejętności bezpośrednio związane z realizacją projektu, takie jak umiejętność monitorowania i budowania zasobu wiedzy strategicznej. Należy zauważyć, że w przewodzeniu grupą zadaniową mniej istotne są działania powodujące rozwój organizacji. Zespół zadaniowy ze względu na ograniczony czas jego funkcjonowania bazuje na wypracowanym ogólnym potencjale rozwojowym. Jednocześnie lider nie jest zwolniony z obowiązku patrzenia na organizację jako całość, powinien więc angażować się i na podstawie zdobytych doświadczeń wskazywać pożądane kierunki rozwoju. Znacznie większe pole działania dla lidera projektu pojawia się w przypadku kształtowania kultury organizacyjnej. Niezbędne jest stworzenie przyjaznego klimatu współpracy, zapewnienie częstych interakcji i skutecznej komunikacji. Skuteczne przewodzenie zespołom zadaniowym wymaga zapewnienia wysokiego stopnia samodzielności, zwłaszcza że pracownicy mają wiedzę ekspercką. Kultura organizacyjna oparta na współpracy powinna obejmować także klienta, czyli odbiorcę projektu. Taka potrzeba jest szczególnie widoczna właśnie w przypadku zarządzania projektowego, gdzie związek grupy zadaniowej z klientem i współpraca z nim są bardzo ścisłe. Dzięki odpowiednio zbudowanej kulturze udaje się osiagnąć spójność wewnętrzną i wytworzyć ducha zespołu. Daje to członkom zespołu poczucie bezpieczeństwa i zwiększa prawdopodobieństwo pojawienia się ostatniej grupy cech, określanej mianem innowacyjności. To właśnie dzięki innowacyjnemu podejściu do projektu możliwe jest osiąnnięcie sukcesu. Niepowtarzalność problemów stojących przed poszczególnymi zespołami projektowymi wymusza konieczność wzbudzania innowacyjności. Nie jest to oczywiście zadanie proste. Wymaga od pracowników odpowiedniego poziomu kompetencji, kreatywności. Niezbędne są też nowoczesne technologie, umiejętność przygotowania nowego produktu czy zastosowania nowego procesu.

Trzeci element, od którego zależy skuteczność wyzwalania przedsiębiorczości w ramach grupy zawodowej, dotyczy mechanizmu transmisji, tzn. przełożenia przedsiębiorczości lidera na przedsiębiorczość grupy. Aby przywództwo było skuteczne, lider projektu musi opierać swoją pozycję na określonych źródłach władzy. Organizacja musi zapewnić odpowiedni zakres uprawnień, które lider projektu może wykorzystać w swojej pracy. Legitymizacja formalna jednak nie wystarcza; ważny jest także umiejętny dobór stylu zarządzania (poziomu centralizacji władzy) oraz instrumentów motywacyjnych. 
Przedstawioną koncepcję kształtowania przedsiębiorczości w ramach organizacji zorientowanej projektowo ilustruje schemat.

Ryc. 4. Proces budowania przedsiębiorczości w organizacji zorientowanej projektowo

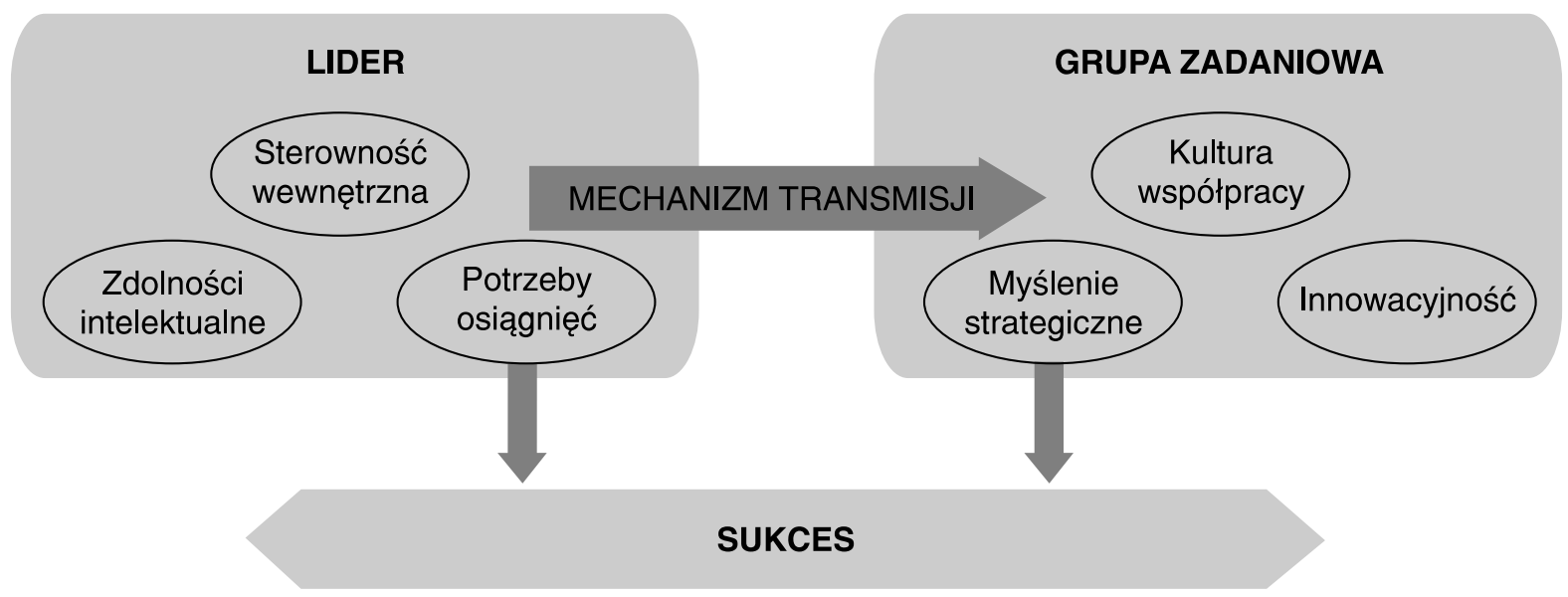

Źródło: opracowanie autorów

Warto spojrzeć na proponowany schemat jako na pewnego rodzaju układ proaktywny, w którym poszczególne cechy spełniają określone funkcje. Zarówno potrzeby osiagnięć na poziomie indywidualnym, jak i myślenie strategiczne na poziomie grupy zadaniowej wskazują kierunek działania. Pojedynczy człowiek będzie je skłonny podejmować, jeśli będzie wierzył w siebie (sterowność wewnętrzna), a grupa - jeśli będzie wewnętrznie spójna (jeśli wytworzy się kultura współpracy). Sukces będzie mógł zostać osiagnięty, jeśli jednostka ma odpowiednie zdolności intelektualne, które pozwolą jej zdobyć przewagę nad innymi. W przypadku grupy zadaniowej instrumentem, który pozwala zdobyć przewagę, jest innowacyjność.

\section{Literatura}

1. Antoszkiewicz J.D., 2002, Przedsiębiorczość w nowej roli [w:] Przedsiębiorczość i rozwój małych $i$ średnich przedsiębiorstw w XXI wieku, B. Piasecki (red.), Wydawnictwo UŁ, Łódź

2. Bratnicki M., 2002, Przedsiębiorczość i przedsiębiorcy współczesnych organizacji, Wydawnictwo AE w Katowicach, Katowice

3. Domachowski W., 1998, Przewodnik po psychologii społecznej, Wydawnictwo Naukowe PWN, Warszawa

4. Francik A., 1994, Przedsiębiorczość a innowacje, „Zeszyty Naukowe” 444/1994, AE w Krakowie, Kraków

5. Griffin R.W., 1999, Podstawy zarzadzania organizacjami, Wydawnictwo Naukowe PWN, Warszawa

6. Heerkens G.R., 2003, Jak zarzadzać projektami, Wydawnictwo RM, Warszawa

7. Holstein-Beck M., 1997, Być albo nie być menedżerem, Infor, Warszawa

8. Innowacje w rozwoju przedsiębiorczości w procesie innowacji, 2004, W. Janasz (red.), Difin, Warszawa

9. Kapitał ludzki a ksztaltowanie przedsiębiorczości, 2004, M. Juchnowicz (red.), Poltext, Warszawa

10. Karwińska A., Mikułowki-Pomorski J., Pacholski M., 2002, Typy działań socjotechnicznych a funkcje organizacji, Wydawnictwo AE w Krakowie, Kraków

11. Kasiewicz S., 1999, Klasyfikacja wskaźników oceny zarzq̨dzania wspótczesnym przedsiębiorstwem, „Organizacja i Kierowanie” 3/1999

12. Kożuch B., 2001, Pojęcie i istota przedsiębiorczości [w:] Praktyczne problemy przedsiębiorczości, H. Wnorowski, A. Letkiewicz (red.), Wydawnictwo Uniwersytetu w Białymstoku, Białystok

13. Kraśnicka T., 2002, Wokót pojęcia przedsiębiorczości, „Przegląd Organizacji” 6/2002 
14. Kuc B.R., 2004, Od zarzqdzania do przywództwa, Wydawnictwo Menedżerskie PTM, Warszawa

15. Kurek Z., 2001, Wprowadzenie do przedsiębiorczości, Olsztyńska Wyższa Szkoła Informatyki i Zarządzania im. prof. T. Kotarbińskiego, Olsztyn

16. Listwan T., 2004, Wpływ potencjału kompetencyjnego menedżerów na jakość kapitału ludzkiego [w:] Kapitał ludzki a kształtowanie przedsiębiorczości, M. Juchnowicz (red.), Poltext, Warszawa

17. Lock D., 2003, Podstawy zarzqdzania projektami, PWE, Warszawa

18. Machaczka J., 2004, Zmiana organizacji jako zjawisko wielowymiarowe, „Przegląd Organizacji” 12/2004

19. Majchrzak J., 2002, Zarzadzanie zmianami w przedsiębiorstwie, Wydawnictwo AE w Poznaniu, Poznań

20. Nowakowski M.K., Wajszczuk J.J., 2003, Globalizacja i biznes. Powrót do źródet i wartości, „Organizacja i Kierowanie" 4/2003

21. Osbert-Pociecha G., 2004, Elastyczność organizacji-atrybut pożqdany a niezidentyfikowany, „Organizacja i Kierowanie" 2/2004

22. Penc J., 2005, Role i umiejętności menedżerskie, Difin, Warszawa

23. Penc J., 2001, Zarzqdzanie w nowej ekonomii, „Przegląd Organizacji” 11/2001

24. Podstawy nauki o przedsiębiorstwie, 1999, J. Lichtarski (red.), Wydawnictwo AE im. O. Langego we Wrocławiu, Wrocław

25. Praktyczne problemy przedsiębiorczości, 2001, H. Wnorowski, A. Letkiewicz (red.), Wydawnictwo Uniwersytetu w Białymstoku, Białystok

26. Przedsiębiorczość i rozwój małych i średnich przedsiębiorstw w XXI wieku, 2002, B. Piasecki (red.), Wydawnictwo Uniwersytetu Łódzkiego, Łódź

27. Przedsiębiorczość w Polsce w perspektywie z integracja Europejska, 2003, M. Trocki, K. Krajewski (red.), Instytut Przedsiębiorczości i Samorządności, Warszawa

28. Psychologia ekonomiczna, 2004, T. Tyszka (red.), GWP, Gdańsk

29. Robbins S.P., 1998, Zachowania w organizacji, PWE, Warszawa

30. Stoner J.A.F., Wankel Ch., 1996, Kierowanie, PWE, Warszawa

31. Stopczyńska K., Karkowski T., 2003, Wykorzystanie aplikacji CRM w kreowaniu pozycji konkurencyjnej przedsiębiorstwa na rynkach zjednoczonej Europy [w:] Przedsiębiorczość w Polsce w perspektywie z integracja europejska, M. Trocki, K. Krajewski (red.), Instytut Przedsiębiorczości i Samorządności, Warszawa

32. Strojny J., Wielowymiarowość zwiazku między przedsiębiorczościa jako cechq osobowości a działaniem matej i średniej firmy, maszynopis pracy doktorskiej, AE w Krakowie

33. Szplit A. (red.), 1996, Leksykon przedsiębiorcy, Wydawnictwo Politechniki Świętokrzyskiej, Kielce

34. Trocki M., Grucza B., Ogonek K., 2003, Zarzqdzanie projektami, PWE, Warszawa

35. Zaleśkiewicz T., 2004, Przedsiębiorczość i podejmowanie ryzyka [w:] Psychologia ekonomiczna, T. Tyszka (red.), GWP, Gdańsk

\section{Entrepreneurship as a Determinant of Competitiveness for a Project-oriented Organization}

Authors start from a theoretical debate about a change, and consequent uncertainty, as a determinant of a company growth and they recognize entrepreneurship as a fundamental attribute of a competitive organization. According to the authors entrepreneurship is strictly related to the innovation of the company. The creation of innovation as well as products development and reasonable use of them on the market, i.e. good interactive marketing and new or enhanced product launched to better fulfill customers' needs and beat the competitors by value advantage - all of these decide on importance and success of the company. In the second part the authors explain how to build entrepreneurship in the project-oriented organization. 